\title{
Tüketicilerin Organik Gıda Satın Alma Motivasyonlarının Zaltman Metafor Çıkarım Tekniği Aracılığıyla İncelenmesi
}

\author{
Hakan Cengiz ${ }^{a}$, Mehmet Şenel ${ }^{\mathrm{b}}$ \\ aKarabük Üniversitesi, Isşletme Fakültesi, Karabük. \\ ${ }^{b}$ Karabük Üniversitesi, Sosyal Bilimler Enstitüsü, Karabük
}

\section{Öz}

Organik gıdalara olan talep ve organik gıda tüketiminin popülaritesi her geçen gün artmaktadır. Organik gıdaları tüketmek ülkemizde yalnızca belirli bir kitlenin benimsediği bir yaşam tarzına özgü olmaktan çımış ve artık birçok Türk tüketicinin ortak noktası haline gelmiştir. Buna rağmen düzenli olarak organik gıda satın alan Türk tüketicilerin motivasyonları hakkında bilinenler oldukça azdır. Bu çalışmada Zaltman Metafor Çıkarım Tekniği kullanılarak sekiz Türk tüketici ile görüşülmüştür. Bu çalışmada uygulanan metafor analizi, organik gıda tüketen tüketicilerin motivasyonlarının anlaşılmasına katkı sağlamaktadır. Analiz sonuçlarına göre; üç derin metafor (bireysel perspektif, toplumsal perspektif ve kazanım/fayda), dokuz tematik kategori (sağlıklı yaşam, sosyal statü aracı, lezzete düşkünlük, doğaya uyumlu yaşama, geçmişe duyulan özlem, çevre bilinci, kültürü yansıtması, yerel ekonomiye destek, iyi hissetme) ve dokuz kavramsal metafor (kalkan, burjuvazi, gurme, doğasever, gelenekçi, koruyucu melek, ayna, tutucu, anti-depresan) ortaya çıkarılmıştır.

Anahtar Kelimeler: Metafor çıkarım tekniği, organik gıda tüketimi, tüketici satın alma motivasyonu

\section{Investigating Consumer Motivations in the Purchase of Organic Foods Using Zaltman Metaphor Elicitation Technique}

\begin{abstract}
The demand for organic foods and popularity of organic food consumption have been increasing day-by-day. Organic foods have shifted from being a lifestyle choice for a small share of consumers to being consumed by many Turkish consumers. However, little is known about the motivations of Turkish consumers who regularly buy organic foods. In this study we interviewed eight Turkish consumers using Zaltman Metaphor Elicitation Technique. Our metaphor analysis contributes to an understanding of consumers' motivations of organic food consumption. We derive three deep metaphor (individualistic perspective, sociological perspective and benefit), nine thematic categories (health, social status, lusciousness seeking, living in harmony with nature, environmental consciousness, nostalgia, cultural mirroring, supporting local farmers, subjective well-being) and nine conceptual metaphors (shield, bourgeoisie, foody, nature lover, traditionalist, guardian angel, mirror, conservative, antidepressant).
\end{abstract}

Keywords: Metaphor Elicitation Technique, organic food consumption, consumer purchase motivation 


\section{GíRiş}

Tarımda kullanılan kimyasal ilaçların hızlı artışı, toprağın çok aşırı kimyasallara maruz kalmasından ötürü verimliliğinin düşmesi ve üretim süreçlerinin yer altı ve üstü su kaynaklarını kirletmesi gibi etkenler çevreye zarar vermektedir. Üretiminde kimyasalların kullanıldığı sağlıksız ürünler çevre ile birlikte insan yaşamını da olumsuz etkilemektedir. Ülkemizde insanların sağlıklı beslenme ve tüketim konusunda bilinçlenmesi ile birlikte organik gıdalara olan talep artmaya başlamıştır. Bu nedenle de üreticiler ve tüketiciler hem çevreyi hem de insan sağlığını koruyacak ve zarar vermeyecek tarım ürünlerini üretme ve tüketme çabası içerisine girmişlerdir. Organik gıda genel anlamıla, yetiştirilmesi ve işlenmesi süreçlerinde hiçbir kimyasal madde kullanılmayan tarım ürünlerini ifade etmektedir.

Ülkemizde organik tarım faaliyetleri Avrupa'da faaliyet gösteren firmaların Türkiye'den organik ürün talep etmeleriyle başlamıştır. Önceleri bu talebi karşılamaya yönelik üretilen organik gıda ürünlerinin tamamı bu yabancı firmalara satılmaktayken (Ataseven ve Güneş, 2008) daha sonraları ülkemizde de organik gıda farkındalığının artması yabancı firmaların oluşturduğu dış pazarın yanı sıra iç pazarın oluşmasını sağlamıştır.

Ülkemiz Gıda, Tarım ve Hayvancılık Bakanlığı'nın tarımsal istatistikleri incelendiğinde 2002 yılında yaklaşık 12.000 olan organik çiftçi sayısı 2015 yılı itibariyle 37.000'e yaklaşmıştır. Bununla birlikte 2015 yılında Türkiye'de 197 adet organik gıda ürünü, yaklaşık 350.000 hektarlık tarım alanı ve yaklaşık 1,2 milyon ton organik gıda üretimi yapılmıştır (Gıda Tarım ve Hayvancılık Bakanlığı, 2015). Bu rakamlar organik ürünlere olan talebin düzeyi ve artan seyri hakkında bilgi vermektedir.

Organik gıda ürünlerinin genellikle stoklarda bekletilmesi mümkün olmamakta ve organik gıda ürünlerinin üretim miktarları iç ve dış pazardaki talepler doğrultusunda belirlenmektedir (Sarıkaya, 2007). Bu doğrultuda tüketicilerin satın alma potansiyellerini arttırmak için organik gida satın alma motivasyonlarını öğrenmek hem uygulamacılar hem de araştırmacılar açısından önem arz etmektedir. Organik gıda tüketiminin insan sağlığı açısından önemi de düşünüldüğünde bu durumun tüketiciler üzerindeki olumlu etkileri de söz konusu olacaktır. Bu nedenle bu çalışmada da tüketicileri organik gida tüketimine yönelten motivasyonların incelenmesi amaçlanmaktadır.

\section{Literatür}

Uluslararası yazın incelendiğinde tüketicileri organik gıdaları satın almaya yönlendiren çok çeşitli faktörlerin olduğu görülmektedir. Organik gıdalar tüketiciler tarafından kimi zaman daha sağlıklı oldukları için tercih edilmekteyken (Makatouni, 2002; Hutchins ve Greenhalgh, 1997), kimi zaman gelenekselleşmiş inorganik gıdalardan daha farklı olarak görüldükleri için satın alınmaktadır (Chinnici, D'Amico ve Pecorino, 2002). Tüketiciler organik gidaların daha yüksek sağlık değerine sahip olduğuna inanmakta, yiyecek alerjilerinden korunmak ve kanser gibi belirli hastalıklara yakalanmamak, yerel ekonomiyi ve adil ticareti desteklemek ve çevreyi 
korumak amacıyla organik ürünler satın almaktadırlar (Siderer, Maquet ve Anklam, 2005). Benzer bir biçimde tüketiciler geleneksel yiyecek üretiminde kullanılan kimyasallardan sakınmak, uzak durmak amacıyla organik ürünleri satın almaktadırlar (Ott, 1990). Buna paralel olarak tüketicilerin çevresel endişelerden dolayı organik ürünler tercih ettikleri de ifade edilebilir (Wandel ve Bugge, 1997). Tüketicileri organik ürün tüketimine yönelten bir diğer faktör ise geleneksel gida üretim süreçlerinde çeşitli kimyasalların ve zirai ilaçların kullanılması olarak ifade edilebilir (Wilkins ve Hillers, 1994).

Organik ürünlerin daha besleyici ve lezzetli olarak algılanması diğer önemli organik tüketim motivasyonları arasında sayılmaktadır (Mitsostergios ve Skiadas, 1994). Buna ek olarak yürütülen bir çalışmada organik ürünlerin yüksek fiyatlı olması nedeniyle daha kaliteli olarak algılandıkları sonucuna varılmıştır (Hill and Lynchehaun (2002). Her ne kadar literatürde bahsi geçen bu yüksek fiyat etkisi, organik ürün tüketiminde bir engel olarak görülse de bazı tüketiciler ödedikleri ücreti organik ürünlerin kalitesinin ve lezzetinin bedeli olarak düşündükleri için bu durumu normal karşılamaktadırlar (Hughner ve diğ., 2007).

Ulusal yazında yer alan sınırlı sayıdaki çalışmadan birinde ise tüketicilerin \%76'ya yakınının organik gıdaları "sağlıklı olması ve güvenilirliği" nedeniyle istediklerini ortaya koymuştur (Armağan ve Özdoğan, 2005). Bu sonuca benzer şekilde bir başka çalışmada ise, organik gıda satın alımına etki eden en önemli faktör "sağlık", ikinci faktör "besleyicilik", üçüncü faktör ise "çevreye duyarlılık" sınıflandırılmıştır. Aynı çalışmada moda ve merak gibi motivasyonların da organik gıda tercihinde etkili olduğu belirtilmesine rağmen ilk üç faktör kadar etkili olmadığ (Çelik, 2013).

Organik gidaların satın alma niyeti üzerine yapılan bir araştırmada ise tutum, sağlık bilinci ve gıda güvenliğinin organik gıda satın alma niyeti üzerinde etkili olduğu tespit edilmiştir (Ustaahmetoğlu ve Toklu, 2015). Bir başka çalışma ise, tüketicilerin organik gida satın alırken yaklaşık olarak, \%30 daha fazla ücret ödemeye hazır oldukları sonucuna varmıştır (Armağan ve Özdoğan, 2005).

Çabuk, Nakıboğlu ve Keleş (2008) yaptıkları çalışmalarında, tüketicilerin organik gıda satın alma davranışlarının; cinsiyet, medeni durum, yaş, eğitim ve gelire göre farklılaştığını ortaya koymuşlardır. Organik gıda satın alan tüketiciler genel olarak kadın, evli, genç, eğitimli ve yüksek gelir düzeyine sahip bireylerdir. Benzer şekilde organik gıdaların algılanmasına ilişkin yapılan bir araştırma sonucunda da evli çiftlerin ve yüksek gelir sahibi insanların organik gıdalara karşı daha duyarlı olduğu (Kacur, 2009), kadınların organik gıdaları erkeklere göre daha olumlu algıladıkları belirtilmiştir (Kacur, 2009; Sarıkaya, 2007), Demografik özellikler ve organik gıda tüketimine ilişkin olarak Çelik (2013)'in yaptığı çalışma cinsiyet, gelir ve eğitim düzeyi gibi demografik etkenlerin organik gıda tüketiminde önemli derecede etkili olduğunu ortaya koymuştur. Ayaz ve Apak (2015) tarafından yapılan çalışmada ise tüketicilerin diğer kolayda mallarda olduğu gibi kolayda gıda ürünlerini düşünmeden satın aldıkları yönündedir. 
Türkiye ile $\mathrm{AB}$ ülkeleri arasındaki düzenli organik gıda tüketimine ilişkin yapılan bir araştırma, $\mathrm{AB}$ ülkelerindeki tüketicilerin düzenli bir şekilde organik gıda tükettiğini fakat Türkiye'de ise organik gida tüketiminin düzensiz ve düşük seviyede olduğunu belirtmiştir (Eryılmaz, Demiryürek ve Emir, 2015). Türkiye'de organik gıda tüketimin düzensiz ve düşük olmasının nedeni ise fiyat yüksekliği ve bilgi eksikliğine bağlı olarak halk tarafından zor benimsenmesi olarak gösterilmektedir (Yanmaz, 2011). $\mathrm{Bu}$ çalışmada Türk tüketicilerin organik gıda tüketim motivasyonlarının ortaya konması sayesinde konuya ilişkin daha detaylı bilgiler elde etmek amaçlanmaktadır.

\section{Yöntem}

Özellikle nicel araştırma yöntemleri benimsenerek yürütülen çalışmalarda ve fokus gruplar gibi araştırma süreçlerinin araştırmacılar tarafından yönlendirildiği çalışmalarda, katılımcıların düşünceleri belirli ölçülerde sınırlandırılmaktadır. Bu tür araştırmalar genellikle katılımcıların zihinlerinde saklı kalan düşüncelerin göz ardı edilebilmesi riski taşımaktadırlar. İçinde yaşadığımız dünyayı ve tecrübelerimizi anlamlandırmada sözlü iletişimin temeli olan dil yetersiz kalabilmekte ve bu nedenle figüratif dil olarak da adlandırılan metaforlar insanlar arasındaki iletişimde önemli rol oynamaktadır (Lakoff, 1993). Bu nedenle bu çalışmada Zaltman Metafor Çıkarım Tekniği (ZMET) kasıtlı bir biçimde tercih edilmiş, bu sayede katılımcıların araştırma sürecine aktif katılımlarını sağlamak ve onların organik ürün tüketim motivasyonlarına ilişkin derinlemesine bilgi sağlamak amaçlanmıştır. Bu tekniğin kullanımına ve izlenen süreçlerin detayına ilerleyen bölümlerde değinilmiştir.

Araştırmacılar araştırmanın amacını ve potansiyel katılımcıların taşıması gereken özellikleri belirttikleri araştırmaya katılım davetini 28.01. 2017 - 08.02.2017 tarihleri arasında üyelikleri bulunan sosyal paylaşım sitelerinde (Facebook ve Twitter) paylaşmışlardır. Bu doğrultuda organik gıda ürünleri tüketen 17 kişiyle ön görüşmeler gerçekleştirilmiş ve bunlardan sekiz katılımcı araştırma sürecine dahil edilmiştir. Katılımcıların, demografik özellikler ve organik gıda tüketim sıklıkları bakımından dengeli bir dağılım göstermeleri arzu edildiği için bazı kişiler araştırmaya dahil edilmemiştir. Bazı kişiler ise organik gıdaları bilinçli/tercihli bir biçimde tüketmedikleri için araştırmaya dahil edilmemişlerdir. Bu bağlamda bu çalışmada nitel araştırmalarda benimsenen ve olasılığa dayalı olmayan amaçlı (kasıtlı) örnekleme yaklaşımı benimsendiği söylenebilir. Amaçlı örnekleme yaklaşımında araştırmanın amacı açısından daha faydalı verilerin sağlanabileceği düşünülen deneklerin ya da olayların seçilmesi esastır (Maxwell, 1997). Araştırmaya katılmayı kabul eden katılımcılara, araştırmanın amacı ve süreçleri hakkında genel bir bilgilendirme yapılmıştır. Daha sonra kendilerinden organik gıda tüketim amaçlarını ve nedenlerini resmedeceğini düşündükleri en az on adet görsel bulmaları ve bu görselleri mülakatlara getirmeleri istenmiştir. Katılımcıların mülakatlara getirdikleri görseller genellikle sosyal paylaşım sitelerinden, arama motorlarından ve dergilerden elde ettikleri fotoğraflardan oluşmuştur. Bunun yanı sıra bazı katılımcılar kendi çektikleri fotoğrafları da beraberlerinde getirmişlerdir. Katılımcılar araştırmacılara toplamda 71 görsel sunmuşlardır. 


\subsection{Zaltman Metafor Çıkarım Tekniği (ZMET)}

Zaltman metafor çıkarım tekniği pazarlama araştırmacıları tarafından sıklıkla kullanılan, tüketicilerin sözle ifade edemeyebileceği metaforik ifadeleri ortaya çıkarmayı amaçlayan bir tekniktir. Bu tekniğin uygulanmasında takip edilmesi önerilen belirli aşamalar bulunmaktadır. Bunlar en genel anlamda fotoğraf tahminleme, bireysel mülakatlar ve nitel veri kodlama olarak ifade edilebilir. Sosyal bilimlerde araştırma sürecinde görsel öğelerin farklı kullanım biçimleri olmakla birlikte ZMET, katılımcıların araştırılacak konu ile ilgili görselleri kendileri temin etmeleri açısından diğer tekniklerden farklılaşmaktadır. Bu doğrultuda bireysel mülakatlar araştırmayı yürütecek kişiler tarafından katılımcıların getirdiği görseller üzerinde tartışarak gerçekleştirilmektedir.

$\mathrm{Bu}$ çalışmada ZMET'in uygulanmasında izlenmesi gereken aşamalardan araştırmanın amacına uygun olan 7 aşama tespit edilmiş ve bu aşamalar takip edilmiştir. Bu aşamalar sırasıyla; görüşmeye getirilen görsellerin öykülenmesi, katılımcıların ulaşamadıkları görsellerin sorgulanması ve açılanması, görsellerin gruplandırılması ve gerekli görülenlerin elimine edilmesi, her bir katılımcının getirdiğ i görseller arasından rastgele seçilen üç görsel arasındaki benzerlikler, farklılıklar ve bu görseller arasındaki bağlantıların açıklanması (yapı çıkarımlama: Kelly Repertory Grid tekniği), katılımcıların organik gıda tüketimine yönelik algılarının görsel olmayan tat, koku, ses ve benzeri hisler açısından değerlendirilmesi, katılımcıların algılarını en iyi temsil eden görselin seçilmesi, katılımcıların algılarına zit düşen bir görselin belirlenmesi, her bir katılımcı için görsel özetlerin oluşturulması olarak belirlenmiştir (Zaltman and Coulter, 1995).

\section{Bulgular}

Bu çalışmada yukarıda bahsedilen aşamalar doğrultusunda Coulter, Zaltman ve Coulter (2001)'in çalışmalarında benimsedikleri metafor analiz süreci ve metaforik kategori oluşturma yaklaşımı genel hatlarıyla benimsenmiştir.

\subsection{Metafor Analizi}

Katılımcılarla gerçekleştirilen mülakatların süresi 1-2 saat arasında değişmiştir. Görüşmeler ses kayıt cihazı ile kaydedilmiş ve kayıtlar görüşme sonrasında metin haline dönüştürülmüştür. Bu sayede her bir görüşmede yer alan metaforik ifadelerin saptanması amaçlanmıştır. Bu doğrultuda araştırmacılar görüşme metinlerini detaylı olarak inceleyerek tematik kategoriler, derin metaforlar ve kavramsal metaforlar oluşturmuşlardır. Bunu takiben kavramsal metaforların ve tematik kategorilerin derin metaforla uyumlu olup olmadığı kontrol edilmiş ve kategorilerde gerekli görülen düzenlemeler yapılmıştır. Tablo 1'de görüldüğü üzere derin metaforlar katılımcıların bireysel ve toplumsal bakış açıları olarak ikiye ayrılmıştır. Bireysel perspektif satırında yer alan tematik kategoriler katılımcıların organik gıda tüketiminde sahip oldukları bireysel motivasyonları göstermektedir. $\mathrm{Bu}$ doğrultuda en genel anlamda katılımcıların organik gida tüketim motivasyonlarının bireysel ve toplumsal olarak sınıflandırıldığı söylenebilir. İlerleyen başlıklar altında her bir tematik kategoriye 
örnek olacak bazı katılımcı ifadeleri seçilmiştir. Bu ifadeler temsili olmakla birlikte katılımcıların tutum ve düşüncelerine ilişkin yüzeysel bilgiler sunmaktadır.

Tablo 1. Derin Metafor, Tematik Kategori ve Kavramsal Metaforların Özetlenmesi

\begin{tabular}{|l|l|l|}
\hline Derin Metafor & Tematik Kategori & Kavramsal Metafor \\
\hline \multirow{5}{*}{ Bireysel Perspektif } & Sağlıklı yaşam & Kalkan \\
\cline { 2 - 3 } & Sosyal Statü Aracı & Burjuvazi \\
\cline { 2 - 3 } & Lezzete düşkünlük & Gurme \\
\cline { 2 - 3 } & $\begin{array}{l}\text { Doğaya uyumlu yaşama } \\
\text { çabası }\end{array}$ & Doğasever \\
\hline \multirow{5}{*}{ Toplumsal Perspektif } & Geçmişe duyulan özlem & Gelenekçi \\
\cline { 2 - 3 } & Çevre bilinci & Koruyucu melek \\
\cline { 2 - 3 } & Kültürü yansıtması & Ayna \\
\cline { 2 - 3 } & Yerel ekonomiye destek & Tutucu \\
\hline Kazanım/Fayda & İyi hissetme & Anti-depresan \\
\hline
\end{tabular}

\subsection{Bireysel Perspektif}

Sağlıklı yaşam; katılımcılar genel olarak organik gıdaların inorganik gidalara göre daha sağlıklı olduğuna inandıklarını ifade etmişlerdir. Buna ek olarak, inorganik gıdaların sağlıklarını bozacağını düşündükleri de söylenebilir. Ayrıca katılımcıların sağlıklarını korumak amacıyla organik ürün tüketmekte olduğu da belirtilebilir. Bu nedenle bu kategorik tema metaforik olarak kalkan şeklinde adlandırılmıştır. Bu doğrultuda katılımcıların sağlıklı yaşam ile organik gıda tüketimini ilişkilendirdikleri gözlemlenmiştir. Schifferstein ve Ophuis (1998) tüketicilerin sağlıklı hissettirdiğinden dolayı organik gıda tükettiklerini belirtmiştir. Bu sebeple katılımcıların inorganik gıda ürünlerine yönelik gıda güvenliği konusunda önemli düzeyde endişeler taşıdıkları ve sağlıklı bir yaşam için organik gıda tükettikleri belirtilmiştir.

Örnek ifadeler: “Bu tür [organik] yiyecekler tükettiğimde kendimi daha iyi hissediyorum (Katılımcı \#3), Organik olmayan ürünler tükettiğimde sağlı̆̆ımın bozulacağına inanıyorum (Katılımcı \#1)."

Doğaya uyumlu yaşama çabasl; bu kategorik tema başlığı altında katılımcıların doğayla uyumlu bir yaşam tarzı oluşturma çabaları ön plana çıkmıştır. Bu bağlamda katılımcılar doğa ile olan ilişkilerini korumak ve geliştirmek amacıyla organik gidalar tükettiklerini ifade etmişlerdir. Ott (1990), tüketicilerin geleneksel üretimde kullanılan kimyasallardan uzak kalarak tamamen doğaya uygun ürünleri tüketme motivasyonuna sahip olduklarını ortaya koymuştur. Ayrıca katılımcıların doğayla uyumlu yaşamadıkları takdirde yapay üretim süreçlerine bağımlı olacaklarına inandıkları görülmüştür. Bu doğrultuda katılımcıların inorganik gıdalar tüketmeyi özgürlüklerini kaybetmekle eşleştirdikleri de gözlemlenmiştir. Bu kategori metaforik olarak doğasever olarak adlandırılmıştır.

Örnek ifadeler: “Bence her şeyin doğal olanı güzel. Yapay olan şeyler bizi hissizleştiriyor ve özümüzden uzaklaştırıyor. Ben o yüzden sürekli organik gidalar tüketmeyi istiyorum. Ama şehir yaşamında bu ne kadar mümkün tartışlır. Tabii 
imkânım ve yerim olsaydı en azından yediğim meyve ve sebzeyi kendim yetiştirirdim." (Katılımcı \#8), "Doğadan ve her şeyin doğal olanından uzaklaştıkça özgürlüğümüz kısıtlanıyor ve üreticilere bağımlı hale geliyoruz. Farkında olmadan her geçen gün doğadan kopuyoruz." (Katılımcı \#4)

Sosyal statü aracl; katılımcılar genel olarak organik gida fiyatlarının yüksek olmasından olayı herkesin organik gıda tüketemediğini ve organik gıda tüketen tüketicilerin sosyal statüleri ve gelirleri yüksek insanlardan oluştuğunu düşünmektedirler. Bu anlamda bu çalışmada katılımcıların organik gıda tüketimini bir sosyal statü aracı olarak gördüğü söylenebilir. Bu nedenlerle bu kategorinin kavramsal metaforu burjuazi şeklinde adlandırılmıştır.

Örnek ifadeler: Günümüzde organik gidaları tüketen insanlara baktığınızda genelde statüsü yüksek insanlar olduklarını görürsünüz. Bence bu durum kişinin kazancı ve eğitim durumu gibi konularla alakalı. Çünkü her şeyden önce organik gıdalar pahalı ve bu tür gıdalara ulaşmak bir farkındalık gerektiriyor. (Katılımcı \#5). Herkes belirli bir yöne doğru gidiyorsa bana göre o yol yanlıştır. Organik gıdaların satıldığı marketlerin sayısı bu durumu gösteriyor. Bu tür reyonlar hep elit semtlerdeki marketlerde. ".......Organik gıdalar satın aldığımda kendimi özel hissediyorum demek istemem ama en azından mutlu ve güvende hissediyorum." (Katılımcı \#3)

Lezzete düşkünlük; Fillion ve Arazi (2002) yaptıkları çalışmada tüketicilerin organik gıdaları diğer gıdalara göre daha lezzetli olarak algıladıklarından dolayı tercih ettiklerini ortaya koymuştur. Bu çalışmada da katılımcılar organik ürünleri lezzetli olduğundan dolayı tercih ettiklerini vurgulamışlardır. Tüketiciler inorganik süreçlerle üretilen gıdaları lezzetsiz ve tatsız bulduklarını ifade etmişlerdir. Bu doğrultuda katılımcıların damak tatlarını ön planda tuttukları söylenebilir. Bu sebeple bu kategori metaforik olarak gurme şeklinde adlandırılmıştır.

Örnek ifadeler: Tabii ki birçok başka nedeni var bu resmi seçmemin. Ama şu görüntü bence her şeyi açılıyor. Tadı asla kötü olamaz bu sofradakilerin (Görseldeki sofradan bahsediliyor). (Katılımcı \#6), "Çürük olsun, görüntüsü kötü olsun umurumda bile değil. Tadı güzel olsun, kokusunu alarak yiyebileyim bana o yeter" (Katılımcı \#2)

\subsection{Toplumsal Perspektif}

Çevre bilinci; bu tematik kategori altında katılımcıların sosyal ve doğal çevrelerini korumaya yönelik güdüleri toplanmıştır. Davies, Titterington ve Cochrane (1995) yaptıkları çalışmalarında tüketicilerin çevre bilinci ile hareket ederek organik gıda tükettiklerini ortaya koymuştur. Bu doğrultuda katılımcılar doğaya, hayvanlara ve yeryüzünde yaşayan diğer insanlara karşı sorumluluklarını yerine getirmek amacıyla organik gıdalar tükettiklerini ifade etmişlerdir. Bazı katılımcılar kapitalist üretim süreçlerinin çevreye ve insani değerlere verdiği zararlardan da bahsetmişlerdir. $\mathrm{Bu}$ sebeple katılımcıların çevreyi koruma içgüdüsüyle organik gıda tükettikleri söylenebilir. Bu doğrultuda bu kategorinin kavramsal metaforu koruyucu melek şeklinde belirlenmiştir. 
Örnek ifadeler: "Ben bilinçsizce tüketen insanlara anlam veremiyorum. Yer yüzünde her eylemimizin bir sonucu olduğunu düşünenlerdenim. Yapmış olduğumuz davranışlardan vicdanen sorumlu hissetmeliyiz. Bana sorarsanız çalışanın hakkına, emeğine sayg1 göstermek için bile organik ürün tercih edilmeli. Toprağa ve yediklerimize karışan, sofralarımıza gelen kimyasalları söylemiyorum bile." (Katılımcı, \#8). “Organik ürünler tüketmeyi bir sorumluluk olarak görüyorum, yeryüzünde yaşayan tüm canlıların yaşam hakkına saygı duymak bunu gerektirir"' (Katılımcı, \#7), "Kapitalist düzene ayak uydurmamısssanız hayatta kalmanız çok zor bugün. En azından sosyal olarak böyle. Aynı şekilde kapitalist düzende organik ürün tüketmek çoğu kişiye komik görünebilir. Ama hala bunun için imkân varken neden yapmayalım. Günü kurtarmak adına yenilecek en güzel şey doğal gidalar (Katılımcı \#3)

Yerel ekonomiye destek: Padel ve Foster (2005) çalışmalarında yerel ekonomiyi destekleme motivasyonunun tüketicileri organik gıda ürünü satın alımına teşvik ettiğini belirtmiştir. Bu tematik kategori kapsamında katılımcılar, organik gıdaların yerel ve küçük ölçekli üreticilerden alınmasının önemli olduğunu vurgulamışlardır. Bu tür yerel satıcılardan alınan ürünler sayesinde ürün güvenliğine ilişkin kaygılarının azaldığını belirtmişlerdir. Ayrıca kapitalist sistem içerisinde sayıları ve gücü her geçen gün azalan çiftçilerin büyük üreticilere karşı güçlendirilmesi üzerinde de durulmuştur. Bu sebeple bu tema kavramsal olarak tutucu şeklinde belirtilmiştir.

Örnek ifadeler: “Elimden geldiğince pazardan alışveriş yaparım. Hatta pazarda küçücük tezgahlarda satış yapan teyzeler ve amcalardan alışveriş yapmaya özen gösteriyorum. Köylerden getirdikleri ürünleri satıyorlar. Bence herkes onlardan almalı. Marketlere acaba şu ürün gerçekten organik mi diye güvenemiyoruz. O yüzden o teyzeleri amcaları küstürmemek lazım. Dedim ya zaten köyden, toprağından getirdikleri belli. Başka yerden satın alıp bize satanlar hariç. Zaten sattıkları şeylerin şeklinden kokusundan belli oluyor kendi yetiştirdikleri." (Katılımcı \#1), "Büyük üretici kazanmasın artık yeter. Bu konuda bilinçlenmeliyiz. Bakıyorsun etrafta manav kalmamış ya da manavın süpermarketten farkı kalmamış. Küçük esnaflara, çiftçilere ulaşmak bizzat onlardan almak lazım. Hem öyle olursa onların kıymeti artar. Üreticiler de onlardan alım yapar, onların teknikleriyle üretim yapar." (Katılımcı \#2)

Kültürü yansıtma; bu kategori kapsamında bazı katılımcılar mülakatlarda belirli bir bölgedeki ya da yöredeki kültürü temsil ettiğini düşündükleri meyve ve sebze görselleri sunmuşlar ve organik gıda tüketim motivasyonlarını bunlar üzerinden ifade etmişlerdir. Katılımcılar organik gıdaların kaybolmaya yüz tutan kültürel değerleri canlandırarak tüketicilere yansıttığını vurgulamışlardır. Bu sebepten dolayı bu tema ayna olarak kavramsallaştırılmıştır.

Örnek ifadeler: Bir kere bizim yemek kültürümüz çok zengin. Mükemmel sofralar hazırlıyoruz. Ama seçtiğimiz yiyeceklerin kalitesi düzgün değilse sofralar nasıl güzel olsun? Her şeyi dalından koparıp sofraya getirdiğin zaman sofra güzel oluyor. Bir kere en başta doğal olmayan yiyecekler bizim kültürümüze ters. (Katılımc1, \#5), “Bu fotoğraftaki meyvenin adı 'taflan' diğeri ise yine Trabzon'da dağlarda yetişen 'lifors'. 
Adları Rumca kökenli. Trabzon'da yaşayan eski kişiler bilir bunları. O yüzden bana sorarsanız bunlar bu kültürün bir parçası (Katılımcı, \#4)

Geçmişe duyulan özlem; Mülakat metinlerinin incelemesinde katılımcıların geçmiş dönemlere duydukları özlem dikkati çekmiştir. Özellikle orta ve üzeri yaş grubu katılımcılar organik gıda tüketimi ile geçmişe duydukları özlemi dile getirmişlerdir. $\mathrm{Bu}$ durum mülakata getirilen görsellere de yansımıştır. Bu grup genellikle köy yaşamı ile şehir yaşamını karşılaştırarak geçmişe duydukları özlemi ifade etmişlerdir. Bu doğrultuda söz konusu katılımcıların bugünle geçmiş arasında sıkça karşılaştırma yaptıkları ve geleneklerinden kopamadıkları görülmüştür. Bu tematik kategorinin derin metafor olarak belirlenen toplumsal perspektif başlı̆̆ altında yer almasının bir nedeni bulunmaktadır. Çünkü katılımcıların genel olarak sanayileşme sonrası yaşanan toplumsal dönüşümden, köyden kente göçten sonra değişen yaşam ve çevre şartlarından yakındıkları görülmüştür. Bu doğrultuda bu kategori gelenekçi olarak adlandırılmıştır.

Örnek ifadeler: “Artık çoğumuz şehirlerde yaşıyoruz. Doğal ürünlere ulaşmak gerçekten zor. Bu yüzden dalından bir sebze koparıp yediğimde geçmişteki güzel günlerimi anımsıyorum." (Katılımcı \#7) “Önceden yediğimiz her şey topraktan geliyor derdik onun [toprağın] bir anlamı vardı. Şimdi [yediklerimiz] nereden geliyor belli değil. Kokusu tadı başkaydı eskiden yediğimiz şeylerin. İnanın arıyorum eskiden yediğim bir domatesin tadını (Katılımcı \#6). “Biz Anadolu insanıyı. Ankara'ya taşınmadan, taa yıllar önce köyümüzde bahçelerimiz vardı. Yerimiz yine var ama şimdi oralarda kimimiz kimsemiz kalmadığı için her yer kurudu. Dalında koparır yerdik her şeyi. Aklımıza şüphe düşmezdi, nerden gelecek aklına acaba bu organik mi diye. Hepsinden bolca yerdik gönül rahatlı̆̆ıyla. Şimdi balkonda apartmanın bahçesinde sebze yetiştircem diye uğraş dur."(Katılımcı \#5).

\subsection{Kazanım/Fayda}

Bu derin metafor altında katılımcılar genel olarak organik gıdalar tüketerek iyi hissettiklerini ifade etmişlerdir. Bu yönüyle çoğu katılımcının günümüzde yaşanan çevresel ve toplumsal problemlerin olumsuz etkisini azalttığını vurgulamışlardır. Bu nedenle bu derin metafor kavramsal olarak anti-depresan şeklinde adlandırılmıştır. Goetzke, Nitzko ve Spiller (2014) organik gida tüketiminin psikolojik olarak iyi hissetme düzeylerini arttırdığını ortaya koymuşlardır. Bu doğrultuda bu çalışmada katılımclar kimi zaman bir sorumluluğu yerine getirdiklerine kimi zamansa sağlıklarını koruduklarına inandıkları için iyi hissettiklerini vurgulamışlardır.

\section{SONUÇ VE ÖNERÍLER}

$\mathrm{Bu}$ çalışmada organik gıda ürünleri satın alan tüketicilerin organik gıda tüketimlerine ilişkin motivasyonları incelenmiştir. Metafor analizinde yapılan görüşmeler neticesinde katılımcıların organik gıda tüketimine ilişkin zihinlerinde bulunan derin anlamlar ortaya çıkarılmıştır. Verilerin analizi sonucunda üç derin metafora: bireysel perspektif, toplumsal perspektif ve kazanım/fayda ve dokuz tematik kategoriye ulaşılmıştır. Bu doğrultuda her kategori metaforik olarak adlandırılmıştır. 
En genel anlamda katılımcıların organik gıda tüketiminde bireysel ve toplumsal motivasyonlara sahip oldukları ve organik gıdaları tüketerek psikolojik olarak iyi hissettikleri görülmüştür. Bu durum organik gıda tüketimine ilişkin literatüre yapılan özgün bir katkı olarak değerlendirilebilir.

Çalışmamızda katılımcılar organik gıda tüketimini sağlıklı yaşamı koruyan bir kalkan, sosyal statü elde ederek burjuvazi sınıfına ait olma aracı, bir gurme gibi lezzet ve haz elde etme ve doğa ile uyumlu yaşama amacı güden bir doğasever olarak düşünmektedirler. Ek olarak katılımcılar artan kent nüfusunun sorunlarından yakındıkları ve köy hayatını özledikleri için organik gıda tüketimini geçmişe duyulan özlem ile ilişkilendirmişlerdir.

Katılımcılar organik gıda tüketiminin ekonomik etkenleri üzerinde de durmuştur. Organik gıda satın alımının yerel satıcılardan yapılmasının hem ürünlerin organik olup olmadığı hususundaki endişeyi ortadan kaldırdığını hem de yerel ekonomiye destek sağladığını belirtmişlerdir. Buna ek olarak bu durumun yaşam standartları üzerinde de olumlu bir etki oluşturacağını ifade etmişlerdir.

Günümüzde hızla gelişen teknolojiye paralel olarak gıda işletmelerinin daha düşük maliyetli üretim olanakları artmıştır. Bu doğrultuda özellikle şehirlerde yaşayan tüketiciler yalnızca ambalajları birbirinden farklılaşan ve raf ömrü uzatılmak için çeşitli kimyasallar içeren gıdalar tüketmek zorunda kalmaya başlamışlardır. Bu durum farklı yaşam tarzlarını benimseyen ve farklı davranışlar sergileyen tüketici gruplarının oluşmasına sebep olmuştur. Sade yaşam ve tüketim karşıtlığı tüketici araştırmaları literatüründe özellikle son dönemlerde araştırmacılar arasında popüler konular arasına girmiştir. Bu doğrultuda katılımcıların ifadelerinde; sade yaşama, kapitalizm ve tüketim karşıtlı̆ına ilişkin unsurların da yansıdığ1 görülmüştür. Küçük ölçekli işletmelerin korunması, çevre bilinci, yerel ekonomiye destek ve doğa ile uyumlu bir biçimde yaşama arzusu bunlara verilecek örnekler arasında sayılabilir. Dolayısıyla tüketicilerin organik gıda tüketme motivasyonları literatürde bahsi geçen kavramlarla da ilişkilendirilebilir.

Bu çalışmada elde edilen sonuçlar literatürde yer alan önceki elde edilen araştırma sonuçlarını destekler niteliktedir (Siderer, Maquet ve Anklam, 2005; Magnusson ve diğ., 2001). Örneğin bu çalışmada elde edilen sonuçlara benzer şekilde Çelik (2013) organik gıdalar ile ilgili olarak sağlıklı, lezzetli, çevreye dost olması, geçmişi anımsatması gibi kategorilere ulaşmış ve bu motivasyonların tüketicileri organik gıda tüketimine yönlendirdiğini belirtmiştir. Literatürdeki önceki çalışmalardan farklı olarak ise; bu çalışmada organik gıda tüketimindeki önemli motivasyonlardan birisinin "kültürü yansıtma" olduğu bulunmuştur. Katılımcılar ülkelerine özgü yemek kültürlerinin olduğunu ve kültüre bütünleşik olarak gördükleri organik gıdaları tüketerek kendilerine özgü kültürlerini tam anlamıyla yaşayabileceklerini düşünmektedirler. Önceki çalışmalara katkı olarak ifade edilebilecek bir diğer tematik kategori ise sosyal statü aracı olarak ifade edilmiştir. Organik gıda tüketimi sayesinde tüketicilerin kendilerini farklı ve ayrıcalıklı hissettikleri gözlemlenmiş, organik tüketimi özellikle şehir yaşamında belirli gelir ve 
eğitim düzeyine sahip kişilerin tercih edebileceğine inandıkları anlaşılmıştır. Bu sonuçlar gerek uygulamacılar gerekse araştırmacılar açısından belirli çıkarımlar yapmaya olanak tanımaktadır. Uygulamacılar bu algıyı değiştirecek tutundurma ve fiyatlandırma stratejileri benimseyerek, kültürel unsurları kullanarak hedef kitlelerini genişletebilirler. Ayrıca elde edilen bulgular tüketicilerin zihninde organik gıda çağrışımı yapan unsurların neler olduğunun tespit edilmesi açısından da önemlidir. Bu çalışmada literatürdeki diğer çalışmalardan farklı olarak ortaya konan kültürü yansıtma, sosyal statü aracı olma ve psikolojik olarak iyi hissetme durumları uygulamacılar tarafından organik gıda ürünlerinin üretilmesinden satışına kadar geçen tüm pazarlama süreçlerinde işlenebilir. Bu motivasyonların kullanılması tüketicilerin zihninde olum bir imaj oluşturabilir ve satın alma konusunda onları harekete geçirebilir.

Araştırmacılar açısından bakıldığında ise bu araştırmada kullanılan yöntem birçok araştırmacıya çalışmalarında kullanmak üzere örnek teşkil edebilir. Çünkü araştırma süreci boyunca katılımcıların kendi getirdikleri görseller üzerinden konuşmaya daha istekli oldukları görülmüştür. Bu çalışmada kullanılan Zaltman Metafor Çıkarım Tekniği (ZMET) önemli bir teknik olmasına rağmen araştırmacılar tarafından fazlaca kullanılan bir yöntem değildir. Gelecekte özellikle nitel araştırma tekniklerinin tercih edileceği araştırmalarda Zaltman'ın bu tekniğinin kullanılması hem tekniğin kullanımının yaygınlaşmasına hem de bu tekniğin farklı alanlarda nasıl kullanılacağına ilişkin yeni görüşlerin gelişmesine de yardımcı olacaktır.

Araştırma sonuçları karar vericiler açısından da önem arz etmektedir. Bu araştırmada katılımcıların sağlık ve çevre bilinci konusunda ifade ettikleri bu anlamda değerlendirilmelidir. Sürdürülebilir tüketim ve çevre olanakları açısından tüketici beklentileri ilgili kamu kuruluşları tarafından tespit edilmeli ve bu doğrultuda çalışmalar yürütülmelidir. Bu çalışmada tüketicilerin özellikle güvenilir gıda konusunda belirli endişeler taşıdıkları görülmüştür. Organik olmayan süreçlerle üretilen gıdalara yönelik algıların yönetilmesinde ve sorunlara çözüm üretilmesinde hiç kuşkusuz karar vericilerin de çıkarması gereken dersler bulunmaktadır. Tarımsal istihdamın arttırılması, üretimde doğal süreçlerin takip edilmesi ve organik üretimin desteklenmesi gibi hususlar bunlara örnek olarak verilebilir.

Her çalışmada olduğu gibi bu çalışmanın da belirli kısıtları bulunmaktadır. Bunlardan ilki araştırmada örneklem seçiminin amaçlı olarak yapılmasıdır. Amaçlı örnekleme özellikle nitel araştırmalarda faydalı sonuçlar doğurmakla birlikte sonuçların genelleştirilmesini zorlaştırmaktadır. Bu doğrultuda elde edilen bulgular tüm organik gıda tüketen Türk tüketiciler üzerinde genelleştirilemez. İkinci olarak bu çalışmada Zaltman Metafor Çıkarım Tekniğinin tüm aşamaları kullanılmamış olması bir kısıt olarak görülebilir. Gelecek araştırmalarda bu tekniğin tüm aşamaları kullanılabilir ve özellikle yöntemin geliştirilmesi maksadıyla videografik teknikler de kullanılabilir. Bu çalışmada bahsi geçen kısıtlar belirli sonuçlar ortaya çıkarabilir. Özellikle örneklemin seçilmesinde amaçlı yaklaşımın benimsenmesi, organik gıda tüketen tüm tüketicilerin motivasyonlarına ilişkin genellemeler yapmayı zorlaştırmaktadır. Ancak bu çalışmada katılımcıların demografik özellikler bakımından dengeli bir dağılım göstermesine özen gösterilmiştir. Buna ilişkin olarak 
Ek 1'de katılımcıların demografik özelliklerine ilişkin bilgiler sunulmuştur. Kısıtların ortaya çıkarabileceği sonuçlardan bir diğeri ise yöntemde kullanılan aşamalara ilişkindir. Bu doğrultuda literatürde ZMET'i kullanan araştırmalarda tercih edilen aşamaların sayısı ve sırasının araştırmanın amacına göre farklılaştığı görülmüştür. Bununla birlikte bu çalışmada ZMET'in geliştiricisi olan Zaltman ve Coulter (1995)'in önerdiği genel aşamalar sırasıyla takip edilmiştir. Yalnızca katılımcıların organik ürün tüketimiyle ilgili olarak zihinlerinde bir kısa film canlandırmalarına yönelik olan aşama katılımcılardan verimli geri bildirimler alınamadığı için uygulanamamıştır.

\section{EKLER}

EK 1: Katılımcların Demografik Özellikleri

Tablo 2. Katılımcıların Demografik Özellikleri

\begin{tabular}{|l|l|l|l|l|l|l|}
\hline $\begin{array}{l}\text { Katılımcı } \\
\text { No: }\end{array}$ & Yaş & Cinsiyet & \multicolumn{1}{|c|}{ Eğitim } & $\begin{array}{c}\text { Medeni } \\
\text { Hal }\end{array}$ & \multicolumn{1}{|c|}{ Meslek } & Gelir \\
\hline 1 & 27 & Kadın & Lisans & Evli & Bankacı & 3000-3999 TLL Arası \\
\hline 2 & 41 & Erkek & İlköğretim & Evli & $\begin{array}{l}\text { Serbest } \\
\text { Meslek }\end{array}$ & 5000 TL Ve Üzeri \\
\hline 3 & 34 & Kadın & Lisansüstü & Bekar & Ev Hanımı & 3000-3999 TL Arası \\
\hline 4 & 22 & Kadın & Lise & Bekar & Öğrenci & 999 TL Ve Altı \\
\hline 5 & 48 & Erkek & İlköğretim & Evli & $\begin{array}{l}\text { Serbest } \\
\text { Meslek }\end{array}$ & 5000 TL Ve Üzeri \\
\hline 6 & 51 & Erkek & İlköğretim & Evli & Emekli & 3000-3999 TL Arası \\
\hline 7 & 43 & Kadın & Lisansüstü & Evli & Doktor & 5000 TL Ve Üzeri \\
\hline 8 & 37 & Kadın & Lisans & Bekar & Tercüman & 3000-3999 TL Arası \\
\hline
\end{tabular}

\section{KAYNAKÇA}

Armağan, G., \& Özdoğan, M. (2005). Ekolojik yumurta ve tavuk etinin tüketim eğilimleri ve tüketici özelliklerinin belirlenmesi. Hayvansal Üretim, 46(2), 14-21.

Ataseven, Y., \& Güneş, E. (2008). Türkiye'de İşlenmiş Organik Tarım Ürünleri Üretimi ve Ticaretindeki Gelişmeler. Uludă̆ Üniversitesi Ziraat Fakültesi Dergisi, 22(2).

Ayaz, N. ve Apak, Ö. C. (2015). Kolayda Gıda Ürünlerini Satın Alma Davranışı Üzerine Bir Araştırma: Bardak Mısır Örneği. Journal of Tourism and Gastronomy Studies. 3(3), 116-124.

Chinnici, G., D'Amico, M., \& Pecorino, B. (2002). A multivariate statistical analysis on the consumers of organic products. British Food Journal, 104(3/4/5), 187-199.

Coulter, R. A., Zaltman, G., \& Coulter, K. S. (2001). Interpreting consumer perceptions of advertising: An application of the Zaltman Metaphor Elicitation Technique. Journal of Advertising, 30(4), 1-21.

Çabuk, S., Nakıboğlu, A. G. B., \& Keleş, C. (2008). Tüketicilerin Yeşil ürün Satın Alma Davranışlarının Sosyo demografik Değişkenler Açısından incelenmesi. Çukurova Üniversitesi Sosyal Bilimler Enstitüsü Dergisi, 17(1). 
Çelik, S. (2013). Kimler, Neden Organik Gida Satin Aliyor? Bir Alan Arastirmasi/Who and Why Buy Organic Food? A Field Research. Selçuk Üniversitesi Sosyal Bilimler Enstitüsü Dergisi, (30), 93.

Davies, A., Titterington, A. J., \& Cochrane, C. (1995). Who buys organic food? A profile of the purchasers of organic food in Northern Ireland. British Food Journal, 97(10), 17-23.

Eryılmaz, G. A., Demiryürek, K., \& Emir, M. (2015). Avrupa Birliği ve Türkiye'de Organik Tarım ve Gıda Ürünlerine karşı Tüketici Davranışları. Anadolu Tarım Bilimleri Dergisi, (30), 199-206.

Fillion, L., \& Arazi, S. (2002). Does organic food taste better? A claim substantiation approach. Nutrition \& Food Science, 32(4), 153-157.

Goetzke, B., Nitzko, S., \& Spiller, A. (2014). Consumption of organic and functional food. A matter of well-being and health?. Appetite, 77, 96-105.

Hill, H., \& Lynchehaun, F. (2002). Organic milk: attitudes and consumption patterns. British Food Journal, 104(7), 526-542.

Hughner, R. S., McDonagh, P., Prothero, A., Shultz, C. J., \& Stanton, J. (2007). Who are organic food consumers? A compilation and review of why people purchase organic food. Journal of consumer behaviour, 6(2-3), 94-110.

Hutchins, R. K., \& Greenhalgh, L. A. (1997). Organic confusion: sustaining competitive advantage. British Food Journal, 99(9), 336-338.

Kacur, L. L. (2009). Erciyes Üniversitesi İ̈BF Akademik ve İdari Personeli ile İ̈BF İşletme Gündüz ve İkinci Öğretim Öğrencilerinin Organik Ürünleri Algılamaları. Erciyes Üniversitesi İktisadi ve İdari Bilimler Fakültesi Dergisi, (33), 249-277.

Lakoff, G. (1993). The contemporary theory of metaphor. In A. Ortony (Ed.), Metaphor and thought, Second edition, Cambridge: University Press Cambridge; 202-251.

Magnusson, M. K., Arvola, A., Koivisto Hursti, U. K., Åberg, L., \& Sjödén, P. O. (2001). Attitudes towards organic foods among Swedish consumers. British food journal, 103(3), 209-227.

Makatouni, A. (2002). What motivates consumers to buy organic food in the UK? Results from a qualitative study. British Food Journal, 104(3/4/5), 345-352.

Maxwell, J. (1997). Designing a qualitative study. In L. Bickman \& D. J. Rog (Eds.) Handbook of applied social research methods (pp. 69-100). Thousand Oaks, CA: Sage.

Mitsostergios, K. T., \& Skiadas, C. H. (1994). Attitudes and perceptions of fresh pasteurized milk consumers: a qualitative and quantitative survey. British Food Journal, 96(7), 4-10.

Ott, S. L. (1990). Supermarket shoppers' pesticide concerns and willingness to purchase certified pesticide residue-free fresh produce. Agribusiness, 6(6), 593-602.

Padel, S., \& Foster, C. (2005). Exploring the gap between attitudes and behaviour: Understanding why consumers buy or do not buy organic food. British food journal, 107(8), 606-625.

Sarıkaya, N. (2007). Organik Ürün Tüketimini Etkileyen Faktörler ve Tutumlar Üzerine Bir Saha Çalışması. Kocaeli Üniversitesi Sosyal Bilimler Enstitüsü Dergisi, 14(2), 110-125. 
Schifferstein, H. N., \& Ophuis, P. A. O. (1998). Health-related determinants of organic food consumption in the Netherlands. Food quality and Preference, 9(3), 119-133.

Siderer, Y., Maquet, A., \& Anklam, E. (2005). Need for research to support consumer confidence in the growing organic food market. Trends in Food Science \& Technology, 16(8), 332-343.

T.C. Gıda Tarım ve Hayvancılık Bakanlığı. (2015) Organik Tarımsal Üretim Verileri. 11.02.2017 tarihinde http://www.tarim.gov.tr/Konular/Bitkisel-Uretim/Organik-Tarim/Istatistikler adresinden erişildi.

Ustaahmetoğlu, E., \& Toklu, İ. T. (2015). Organik Gıda Satın Alma Niyetinde Turum, Sağlık Bilinci ve Gıda Güvenliğinin Etkisi Üzerine Bir Araştırma. International Journal of Economic E Social Research, 11(1).

Wandel, M., \& Bugge, A. (1997). Environmental concern in consumer evaluation of food quality. Food quality and preference, 8(1), 19-26.

Wilkins, J. L., \& Hillers, V. N. (1994). Influences of pesticide residue and environmental concerns on organic food preference among food cooperative members and nonmembers in Washington State. Journal of Nutrition Education, 26(1), 26-33.

Yanmaz, R. (2011). Organik Ürünlerin Pazarlanması ve Ticareti.

Zaltman, G., \& Coulter, R. H. (1995). Seeing the voice of the customer: Metaphor-based advertising research. Journal of advertising research, 35(4), 35-51. 